ORIGINAL ARTICLE

PRACA ORYGINALNA

\title{
EFFECTIVE USE OF VARIOUS MINIMALLY INVASIVE TECHNOLOGIES ELIMINATING VERTICAL REFLUX IN THE TREATMENT OF CHRONIC DISEASES OF THE LOWER LIMB VEINS
}

DOI: 10.36740/WLek202002124

\author{
Serhiy I. Savolyuk, Valentyn A. Khodos, Roman A. Herashchenko, Vladyslav S. Horbovets \\ SHUPYK NATIONAL MEDICAL ACADEMY OF POSTGRADUATE EDUCATION, KYIV, UKRAINE
}

\begin{abstract}
The aim: To analyze and evaluate the efficacy of CDLLV treatment, using high-frequency endovascular welding (EVW), endovenous laser coagulation (EVLC) and catheter microfoam echosclerotherapy.

Materials and methods: We have treated 329 patients with CDLLV C2-C6 functional classes according to the Clinical Etiological Anatomical Pathophysiology. 0 f these, 102 patients had vertical reflux eliminated by EVW, in 112 - by EVLC, and in 115 - by catheter microfoam echosclerotherapy.

Results: In the EVW group 3 patients (2.94\%) had a partial recanalization of coagulated veins 3 months after the procedure. In EVLC group 2 patients (1.79\%) also had partial recanalization group after 6 months. In the group of catheter microfoam echosclerotherapy partial recanalization occurred in 3 patients during 3 months of observation, in the period of 6 months - in 2, in the period of 12 months - in 9, in total - in 14 patients (12.17\%). The EVW and EVLC methods showed high efficacy of vertical reflux elimination on the great and small subcutaneous veins (GSV/SSV) in CDLLV and have no fundamental differences in the immediate and long-term results of treatment. Microfoam catheter echosclerotherapy leads to a greater number of recanalisations, compared with EVW and EVLC.

Conclusions: High-frequency endovenous welding results in complete fibrotic GSV/SSV transformation in $97.06 \%$ of patients. Endovascular laser coagulation results in complete fibrotic GSV/SSV transformation in $98.21 \%$ of patients. Elimination of vertical reflux by microfoam echosclerotherapy results in complete fibrotic GSV/SSV transformation in $87.83 \%$ of patients.
\end{abstract}

KEY WORDS: chronic vein diseases, endovenous electric welding, laser coagulation, echosclerotherapy

Wiad Lek. 2020;73(2):329-331

\section{INTRODUCTION}

One of the problems in modern surgery is CDLLV. The elimination of vertical reflux by the method of subcutaneous vein removal, using a probe, has several disadvantages associated with the traumatization of adjacent tissues, lymphatic collectors, subcutaneous nerves, formation of major hemorrhages and hematomas. This has led to the search for less traumatic ways to stop pathological reflux on GSV/SSV.

In recent years, the EVLC method has been widely used in the world [1]. Another method of eliminating reflux by VSM, VSP is catheter microfoam echosclerotherapy [2-4]. Data on high frequency EVW GSV/SSV are available in the literature [5-9].

\section{THE AIM}

To analyze and evaluate the efficacy of CDLLV treatment, using high-frequency EVW, EVLC and catheter microfoam echosclerotherapy.

\section{MATERIALS AND METHODS}

We have treated 329 patients with CDLLV C2-C6 functional classes according to CEAP. Of these, 102 patients had vertical reflux eliminated by EVEW, in 112 - by EVLC, and in 115 - by catheter microfoam echosclerotherapy.

The EVEW group included 102 patients (men and women) (C2 - 64 patients, $\mathrm{C} 3-26, \mathrm{C} 4-3, \mathrm{C} 5-4, \mathrm{C} 6-5)$. Their age ranged from 24 to 73 years (average age was 43.2 44.3 ). GSV reflux was found in 98 (96.08\%), SSV - 4 (3.92\%).

The EVLC group consisted of 112 men and women (C2 - 68 patients, C3 - 19, C4 - 14, C5 - 8, C6 - 3) aged 22 to 69 years (average age was $41.4 \pm 3.6)$. GSV reflux was found in $103(91.96 \%)$, SSV - 9 (8.04\%).

The catheter microfoam echosclerotherapy group consisted of 115 men and women (C2 - 65 patients, C3 - 24, C4 - 9, C5 - 4, C6 - 13). Their age was 23-67 years (average age was $39.6 \pm 3.8)$. GSV reflux was recorded in $94(81.74 \%)$, SSV - $21(18.26 \%)$.

Ultrasound duplex angioscans (ultrasound) were performed with a TOSHIBA Nemio XG (Japan), equipped with a convex sensor with an operating frequency of 3.5-5 $\mathrm{MHz}$ and a linear sensor in the range of 7.5-12 MHz.

The EVW device consists of EC $300 \mathrm{M}$ apparatus (Swarmed, Ukraine) and an endovenous welding catheter (EC). The working part of EC is in the form of a bipolar configuration of electrodes with a diameter of up to $3 \mathrm{~mm}$ and length of up to $5 \mathrm{~cm}$. The operating cycle (OC) of the 
welding is performed at a voltage of from 10 to $100 \mathrm{~V}$, AC frequency from 50 to $500 \mathrm{kHz}$, with modulation from 0 , 1 to $250 \mathrm{kHz}$, with tissue resistance of 0.1 to $1000 \mathrm{ohms}$. Duration of the OC is $5-12$ seconds.

The EVW technique was consistent with conventional techniques for minimally invasive endovascular procedures: vein puncture under ultrasound duplex angioscopy (ultrasound), welding catheter import and positioning, tumescent anesthesia. In the area of saphenous-femoral junction (SFJ), the distal pole of the welding catheter was positioned at the ostium of the v.epigastrica, in saphenous-popliteal junction (SPJ) $-1 \mathrm{~cm}$ from v.poplitea. Ablation was performed sequentially in each section of the vein $5 \mathrm{~cm}$ long.

In our practice, EVLCs were performed using a 30 $\mathrm{W}$ laser coagulator with $1470 \mathrm{Nm}$ wavelength. Flexible disposable quartz-polymer optical fibers with radial lens were used at the distal end of the fiber. The optical fiber was $400-600$ microns diameter with $10-18$ watts power.

The technique of catheter microfoam echosclerotherapy of saphenous veins was as follows: a puncture of the saphenous vein was performed with $14 \mathrm{G}$ needle catheter on the lower border of the reflux under ultrasound control. A plastic angiographic catheter $4 \mathrm{~F}$ was introduced into the lumen of the vein through a catheter from a needle-catheter for microfoam transport. The end of the catheter was installed at a distance of $2-3 \mathrm{~cm}$ from SFJ, SPJ. Then, introduction of the first dose of microfoam in a volume of 2-3 $\mathrm{ml}$ began through the catheter, sending it to the area of SFJ or SPJ.

In order to maximally prevent distribution of the microfoam into the deep venous system, the SFJ or SPJ was blocked at the time of its visualization in the junction area by pressing the sensor in the junction projection. Retrograde distribution of the microfoam was blocked by pressing the vein with another sensor $8-10 \mathrm{~cm}$ distal to the compression area in the junction area. At the time of the junction area treatment with microfoam its distribution was observed in the ostium tributaries. After 5-7 minutes, making sure in a satisfactory general condition of the patient, the catheter was gradually withdrawn with simultaneous introduction of the next similar dose of microfoam, distributing it evenly in the distal direction over the next segment of the vein $8-10 \mathrm{~cm}$ long. The interval from the time of microfoam preparation and the beginning of its introduction into the lumen of the vein was 3-5 seconds. In general, all the required doses of microfoam were administered in 2-5 stages for 10-20 minutes, depending on general condition of the patient and the length of the insufficient segment GSV or SSV. The total dose of microfoam per session did not exceed $10 \mathrm{ml}$.

The pathological process was localized monolaterally in all patients. In total, 329 operations were performed on the saphenous veins. Operations on the saphenous veins in all groups were supplemented by miniflebectomy or phlebosclerosis of varicosally altered ostium tributaries. In the postoperative period all patients used compression knitwear of the second class compression.

The effectiveness of vertical reflux elimination by various minimally invasive endovenous methods was assessed according to ultrasound data. The criteria for evaluating the efficacy were presence of occlusion, development of fibrosis, occurrence of recanalization in time of $1,3,6,12$ months after surgery.

\section{RESULTS AND DISCUSSION}

Changes in the EVW and EVLC Ultrasound groups were similar. On the first day after surgery in both groups the coagulated vein had a linear structure, the lumen completely filled with hyperechogenic thrombotic masses, tightly fixed to the walls of the vein. There was a decrease in GSV/SSV diameter, uneven wall thickening, no compression of the vessel by the sensor, no signs of blood flow in ultrasound examination with color mapping. The GSV/SSV obliteration limit with the SFJ, SPJ area was clear, smooth, with no signs of flotation, which could be described as «a thermal crossectomy» effect. Damage to the paravasal adipose tissue was not observed in both methods.

After 1 month, both after the EVW and EVLC, the outlines of the veins lost their clarity, hyperechogenic structures were observed in the lumen, the boundary between them and the vein wall was erased. Differentiation between the vein and surrounding tissues also decreased.

3 months after EVW, 3 (2.94\%) patients had a partial GSV recanalization. In 1 patient recanalization had no hemodynamic significance, but needed further observation, in 2 patients hemodynamically significant recanalization was eliminated by microfoam echoscleotherapy. GSV/SSV in the rest of the patients after EVW and EVLClooked like hyperechogenic gravity without clear contours for 3 months, but with clearer visualization in the ostium area. At this time ultrasound signs showed fibrotic transformation of coagulated veins.

For 6 months in the EVLC group, 2 (1.79\%) patients underwent partial recanalization. In one case it was hemodynamically insignificant, in the other -hemodynamically significant. Hemodynamically significant recanalization was eliminated by the method of microfoam echosclerotherapy. In the remaining patients further fibrotic GSV/SSV transformation was observed 6 months after thermal exposure which looked like a fine fibrous strand of $2-3 \mathrm{~mm}$ in diameter.

After 12 months, both the EVW group, and the EVLC GSV/SSV group underwent complete connective tissue transformation and merged with the surrounding tissues.

In the group of patients who underwent catheter microfoam echosclerotherapy, the process of GSV/SSV fibrotic transformation followed the same steps as after EVW/ EVLC, had a similar ultrasound pattern, but, unlike thermal factors, proceeded more slowly.

After microfoam echosclerotherapy during the observation period of 3 months recanalization occurred in 3 patients, during 6 months - in 2, during 12 months -in 9, in total - in 14 (12.17\%). Recanalization was not hemodynamic in 4 patients out of 14 . In our observations the primary catheter microfoam echosclerotherapy procedure resulted in GSV/SSV complete fibrotic transformation in $87.83 \%$ of patients, which was slightly different from the results of other authors $[1,10,11]$. In 10 patients, hemo- 
dynamically significant recanalization was eliminated by repeated microfoam echosclerotherapy. In 2 patients out of 10 , recanalization occurred again and was eliminated by the third session of microfoam echosclerotherapy.

High-frequency EVW and EVLC have showed high efficacy in the elimination of vertical reflux on GSV/SSV in CDLLV and have no fundamental differences in the immediate and long-term results of treatment.

Microfoam catheter echosclerotherapy leads to a greater number of recanalisations, compared with EVW and EVLC. However, the ability to perform repeat sessions, which patients endure easily, eventually allows you to achieve similar results with thermal technology results. Microfoam echosclerotherapy can be successfully used to eliminate recanalisations that occur after EVW or EVLC.

\section{CONCLUSIONS}

A high-frequency endovenous welding method results in complete fibrotic GSV/SSV transformation in $97.06 \%$ of patients.

Endovascular laser coagulation results in complete fibrotic GSV/SSV transformation in $98.21 \%$ of patients.

Elimination of vertical reflux by catheter microfoam echosclerotherapy results in complete fibrotic GSV/SSV transformation in $87.83 \%$ of patients.

Repeated sessions of microfoam echosclerotherapy allow us to complete fibrous GSV/SSV transformation in $96.52 \%$ of patients.

\section{REFERENCES}

1. van derVelden SK, Biemans AA, De Maeseneer MG, Kockaert MA, Cuypers PW, Hollestein LM, et al. Five-year results of a randomized clinical trial of conventional surgery, endovenous laser ablation and ultrasound-guided foam sclerotherapy in patients with great saphenous varicose veins. $\mathrm{Br}$ J Surg. 2015;102(10):1184-1194.

2. Khodos VA. Pobochnye dejstvija i oslozhnenija mikropennoj stvolovoj skleroobliteracii pri varikoznoj bolezni, mery po preduprezhdeniju i ustraneniju [Side effects and complications of microfoam stem scleroobliteration in varicosity, measures to prevent and eliminate]. Novosti khirurgii. 2017;25(1):38-43. (Ua)

3. Cavezzi A, Parsi K. Complications of foam sclerotherapy. Phlebology. 2012;27(I):46-51.

4. Darvall KA, Bate GR, Adam DJ, Silverman SH, Bradbury AW. Duplex ultrasound outcomes following ultrasound guided foam sclerotherapy of symptomatic recurrent great saphenous varicose veins. Eur J Vasc Endovasc Surg. 2011;42(1):107-114.

5. Horbovets VS, Savoluk SI, Dyadyk 00, Gvozdiak MM, Gerashchenko RA. Rozrobka ta pershyj dosvid zastosuvannja avtomatychnogo rezhymu endovenoznogo elektrozvarjuvannja $v$ likuvanni varykoznoi hvoroby nyzhnih kincivok [Elaboration and first application of endovenous electric welding during varicose vein diseases treatment]. Art of medicine. 2018;4(8):35-43. (Ua)

6. Chernukha LM, Horbovets VS, Vlaykov GG, Savoluk SI, Hodos VA, Dyadyk 00, Kunkik DD Mozhlyvosti zastosuvannja zvarjuvalnoi tehnologii $v$ likuvanni varykoznoi hvoroby nyzhnih kincivok [Possibilities of application of welding technology in the treatment of varicose veins of the lower extremities]. Clinical phlebology. 2019;11(1):43-44. (Ua)
7. Savolyuk SI, Gorobets VS, Khodos VA, Gerashchenko RA. Endovenozne elektrozvarjuvannja velykoi pidshkirnoi veny u likuvanni varykoznoi hvoroby [Endovenous electric welding obliteration of large subcutaneous vein in treatment of varicose disease]. Klinichna khirurhiia. 2017;1:2932. (Ua)

8. Savoluk SI, Khodos VA, Gerashchenko RA, Gorbovets VS. Pershij dosvid vikoristannja endovenoznogo elektrozvarjuvannja v kompleksnomu hirurgichnomu likuvanni gostrogo vishidnogo tromboflebitu velikoï pidshkirnoï veni [The first experience of using endovascular electric welding in the complex surgical treatment of acute ascending thrombophlebitis of a large subcutaneous vein]. Surgery of Ukraine. 2018;3(67):63-67. (Ua)

9. Dyadyk 00, Savolyuk SI, Herashchenko RA, Khodos VA, Horbovets VS. Development of obliteration in the great saphenous vein after influence high-frequency endovenous welding by data of morphological and ultrasonic studies. Wiad Lek. 2019;72(8):1447-1452.

10. Kurdal AT, Yildirim F, Ozbakkaloglu A, Iskesen I, Tetik 0. Ultrasoundguided catheter-directed foam sclerotherapy for great saphenous vein. Minerva Chir. 2015;70(1):33-36.

11. Shadid N, Ceulen R, Nelemans P, Dirksen C, Veraart J, Schurink GW, van Neer P, vd Kley J, de Haan E, Sommer A. Randomized clinical trial of ultrasound-guided foam sclerotherapy versus surgery for the incompetent great saphenous vein. Br J Surg. 2012;99:1062-1070.

\section{ORCID and contributionship:}

Serhiy I. Savolyuk - 0000-0001-5406-8228

Valentyn A. Khodos - 0000-0003-0150-3868 A,F

Roman A. Herashchenko - 0000-0001-6582-9934C,E

Vladyslav S. Horbovets - 0000-0003-1744-9544

\section{Conflicts of interest:}

Authors declare no conflict of interest.

\section{CORRESPONDING AUTHOR Roman A. Herashchenko \\ Shupyk National Medical Academy of Postgraduate Education Str. Salyutnaya 19, apt. 19, 04111, Kyiv, Ukraine \\ tel: +380971090930 \\ e-mail: patholognew@ukr.net}

Received: 10.09.2019

Accepted: 27.12.2019

\footnotetext{
A - Work concept and design, B - Data collection and analysis, C - Responsibility for statistical analysis, D -Writing the article, $\mathbf{E}$ - Critical review, $\mathbf{F}$ - Final approval of the article
} 